\title{
A FORMAÇÃO DE PROFESSORES DA EDUCAÇÃO INFANTIL NO MUNICÍPIO DE OUVIDOR (GO).
}

\author{
Altina Abadia da Silva1; Eliane Gomes de Goveia²; Mikaelli Carín \\ Tavares Silveira ${ }^{3}$.
}

\section{Resumo}

Este trabalho originou-se de uma pesquisa cujo objetivo foi analisar a formação continuada de professores da Educação Infantil do Município de Ouvidor (GO) procurando entender como são constituídos os espaços formativos desses professores e quais os impactos dessa formação recebida, na sua prática pedagógica. $O$ Referencial Teórico adotado foi a Psicologia Histórico-Cultural, com ênfase no conceito vygotskyano de mediação por ser ele central na teoria de Vygotsky e por entendermos a mediação pedagógica como condição maior do trabalho docente. Segundo Vygotsky (1998), mediação, é o processo de intervenção de um elemento intermediário numa relação; a relação deixa, então, de ser direta e passa a ser mediada por esse elemento. Além disso, a opção por esse tema está relacionada também com o fato de trabalharmos com a formação inicial de professores e por desenvolvermos projetos de extensão com os docentes deste município. Através de observações realizadas nos encontros de planejamento de professores da préescola, nas reuniões coletivas quinzenais realizadas pela secretaria de educação do município e pelas entrevistas com um grupo de professores e gestores realizamos a investigação de como ocorriam, até o ano de 2015 a formação continuada dos professores da Educação Infantil. Encontramos indicativos da ineficiência da formação continuada recebida pelas professoras, por se pautar na racionalidade técnica e ainda na imitação de um professor modelo

\footnotetext{
1 Pedagoga; Mestre em Psicologia e doutora em Educação. Professora adjunta da Unidade Acadêmica Especial de Educação - PPGEDUC - Regional Catalão/UFG. tina@wgo.com.br

${ }^{2}$ Pedagoga pela Universidade Federal de Goiás, professora de Educação Infantil. Participante do Núcleo de Pesquisa Infância e Educação - NEPIE. eliane.delgado@hotmail.com

${ }^{3}$ Graduanda do Curso de Pedagogia da Unidade Acadêmica Especial de Educação - Regional Catalão/UFG. .Bolsista PROLICEN - UFG/RC. mikaelli-carin@hotmail.com
} 
que transmitia a seus pares, atividades e concepções de acordo com a sua interpretação e compreensão, impossibilitando que os professores refletissem de maneira crítica e autônoma sobre a sua prática pedagógica. Ademais, constatamos que a partir do ano de 2016, após o início de um curso de formação continuada, desenvolvido por um núcleo de pesquisa da Universidade Federal de Goiás - Regional Catalão, com os professores da Educação Infantil da rede municipal de Ouvidor (GO), através de sessões reflexivas, os professores têm tido oportunidade de refletir sua prática docente, os conceitos e pré-conceitos apreendidos nos seus cursos de formação inicial, na vulnerabilidade da formação inicial que reverbera na prática pedagógica e na compreensão de como se dá o desenvolvimento infantil. Para atingir o objetivo da pesquisa procuramos possibilitar uma experiência de produção em conjunto; professoras da Educação Infantil, professoras formadoras e pesquisadoras. De modo que esse procedimento reúne ao mesmo tempo dois aspectos; a formação e a produção de dados da pesquisa. E assim, a partir das sessões reflexivas, nas escolhas feitas pelo grupo, vamos percebendo/discutindo qual a concepção de criança, educação, desenvolvimento, e aprendizagem se apresenta.

Palavras Chave: Formação de professores; Educação infantil; Processos formativos. 